\section{Bringing Collaboration and Differentiation Into the College Classroom}

\author{
Ashley Stich
}

\section{ABOUT THE AUTHOR}

Ashley Stich serves as the Developmental Education Coordinator for the Maricopa County Community College District and as a faculty member at Mesa Community College in Arizona. She has presented on topics such as small group stations and the use of interactive notebooks at the National Association for Developmental Education's annual conferences. She is currently a doctoral student at Sam Houston State University in the Developmental Education Administration program.

- he classroom buzzes with student chatter. A small group in one corner laughs over a hand-scribbled picture. Groups of students sit clustered around tables as they pass slips of paper. To an outsider, it may appear that the students have taken over the class; to the teacher, it is obvious that they are fully engaged in their own learning. This engagement is the key reason I use review stations in my classroom.

Review stations are an easy way to begin incorporating small group instruction into the college classroom. The use of review stations allows for collaboration, physical participation, and critical thinking (Hennessy \& Evans, 2006; Tinto, 1997). Recent research also suggests small-group activities can build student self-awareness and comfort in the classroom (Leisey, Mulcare, Comeford, \& Kudrimoti, 2014; Yamauchi, Taira, \& Trevorrow, 2016). During a typical review station day, my students participate in three to four stations for 10-15 minutes each. In these stations, students explore the content they have been learning in new and engaging ways.

Though these stations can be used to review a variety of topics and skill-from equations and formulas to psychological theories and musical notation-one of the easiest places to start is with vocabulary review. On review station days, my students know to expect at least one station containing vocabulary terms we have been learning. Almost any workbook-style practice can be turned into a station. For example, many textbooks have students correctly identify which word is missing from a sentence. I write these sentences on sentence strips and give the words to be used on smaller pieces of paper. Students then work in groups to place each word in the correct sentence. By taking this activity out of the textbook and putting into the students' hands, the activities become more engaging and require students to discuss and debate what they know in order to all agree on the answers. Playing Pictionary, creating test questions of their own to quiz their group members, and debating the merits of an argumentative piece of writing are a few other stations I use regularly.

Review station days give my students a chance to practice and determine for themselves where they need to spend more time studying. I remind my students to take note of stations they struggle with in order to help guide their independent study time. As the facilitator of these stations, I am able to tailor my instruction as students move from activity to activity. Walking around the groups, I overhear misconceptions or confusion and can quickly give one-on-one support to correct these issues. The time spent in stations allows everyone in class the opportunity to get into deeper conversations regarding the concepts and skills we practice. Review stations have become an essential piece of my classroom and an important part of my students' active learning.

\section{References}

Hennessy, D., \& Evans, R. (2006). Small-group learning in the community college classroom. Community College Enterprise 12(1), 93-110.

Leisey, M., Mulcare, D., Comeford, L., \& Kudrimoti, S. (2014). Exploring team-based learning at a state university. Interdisciplinary Journal of Teaching and Learning, 4(3), 172-185.

Tinto, V. (1997). Classrooms as communities: Exploring the educational character of student persistence. Journal of Higher Education, 68(6), 599-623.

Yamauchi, L., Taira, K., \& Trevorrow, T. (2016). Effective instruction for engaging culturally diverse students in higher education. International Journal of Teaching \& Learning in Higher Education, 28(3), 460-470. 